\title{
Reproductive Responses, Metabolic Disorder, Ruminal Fermentation Characteristics, and Milk Production of Postpartum Holstein Cows Fed Steam Flaked of Corn and Barley Grains
}

\author{
N. Ahmadijoo, H. Mansoori-Yarahmadi*, J. Fakhraei, \& M. Changizi \\ Department of Animal Science, Faculty of Agriculture, Arak Branch, Islamic Azad University, Arak, Iran \\ *Corresponding author: h-mansouri@iau-arak.ac.ir \\ (Received 23-12-2019; Revised 09-05-2020; Accepted 11-05-2020)
}

\begin{abstract}
This study evaluated the effects of steam flaked of corn and barley grains on the reproductive response, ruminal fermentation characteristics, metabolic disorder, and milk production of postpartum Holstein cows. A total of 40 postpartum Holstein dairy cows were divided into 4 groups $(n=10)$ and fed 1) ground grains (control), 2) steam flacked corn+milled barley, 3) steam flacked barely+milled corn, and 4) steam flaked corn and barley. The animals were treated for 0-30, 30-60, 60-90, and 90120 days post-calving. Milk yield and compositions, total conception rate, endometritis, pyometra, ruminal fermentation characteristics, ketosis, and acidosis were assessed. This study was conducted in a completely randomized design. The results showed that dietary inclusion of steam flaked grains improved milk yield and compositions during the experimental period compared to the control group $(\mathrm{p}<0.05)$, except for cows treated for $0-30 \mathrm{~d}$ days post-calving. Cows fed steam flaked grains showed a lower occurrence of reproduction and metabolic disorders compared to the control group $(\mathrm{p}<0.01)$. Cows fed a combination of steam flaked grains showed better pregnancy rates in the first 100 days and open days of postpartum cows compared to cows in control and a single form of steam flaked barley or corn $(p<0.05)$. Total VFA, acetate, propionate, butyrate, and valerate were higher in cows fed steam flaked compared to the control group $(\mathrm{p}<0.05)$. Feeding steam flaked grains is advised for improving reproductive performance, milk variables, and rumen fermentation profiles in dairy cows.
\end{abstract}

Keywords: corn flaked; metabolic disorder; postpartum cow; reproduction performance

\section{INTRODUCTION}

Dairy cows produce a significant amount of milk (Atmakusuma et al., 2019), but dairy husbandry faces major challenges for management and improvement of reproductive disorders and milk production during postpartum. Metabolic and reproductive disorders with the intensification of milk production have received much attention in high-producing dairy cows (Dobson et al., 2008). The influence of dietary factors may positively and/or negatively influence microbial enzyme activity and animal production (Moharrery et al., 2017).

Feed processing technology has received a growing interest in increasing the nutrient supply and nutritive value of feed in the diets of dairy cows during the recent decade. Feed grains containing starch such as barley and corn need processing prior to feeding for increasing accessibility of the endosperm by microbes in the rumen and the host enzymes in the intestine (Safaei \& Yang, 2017). To provide high energy in dairy cow diets, the cereal grains are included and/or cereal starch is processed (Corato et al., 2005; Koing \& Beauchemin, 2011). Heat treatment of cereal grains by using high moisture may improve their feeding values for ruminants by influenc- ing the total tract starch and protein digestions and their post-ruminal digestion during the steam flaking process (Zinn et al., 2002, Razzaghi et al., 2016). The steam flaking of cereal grains improves digestibility because this process causes physical damage to the starch-protein matrix, granule structure, and the starch gelatinization (Kokić et al., 2013). Food processing increases the nutrient availability and causes a balance between maximizing and controlling the rate of starch digestion in the rumen (Koing \& Beauchemin, 2011). A large scale of steam flaked corns is used in the dairy ration for maintaining a high level of milk production (Xu et al., 2018). A few studies have also evaluated the effect of cereal grains processing methods on postpartum performance in the dairy cow industry. Nikkhah et al. (2004) showed that the inclusion of steam-flaked broom sorghum versus ground broom sorghum is a more efficient source of energy in lactating cows. Safaei et al. (2016) showed that processing methods such as steam flaking improves performance and feed utilization in dairy cows fed low-forage diets. It was reported that the steam flaking process of grains increases the proportion of fermented starch in the rumen and its intestinal digestion that increases the available energy for milk production (Theurer et al., 
1995). Seemingly, steam flaking can have beneficial effects on dairy cows. However, any study has not been conducted to evaluate the effects of steam flaking of barley and corn grains on the reproductive response, ruminal fermentation characteristics, and milk production of postpartum Holstein cows. This study was thus conducted for the first time to investigate the effects of steam flaking of barley and corn grains on ruminal fermentation characteristics, reproductive response, and milk production of postpartum Holstein cows.

\section{MATERIALS AND METHODS}

\section{Location and Grain Processing}

This study was performed at a dairy farm in Qom Province, Iran $\left(34^{\circ} 40^{\prime} \mathrm{N}\right.$ and $\left.51^{\circ} 0^{\prime} \mathrm{E}\right)$ from January to April 2018. Qom Province is a region with annual temperature in the range from $-10^{\circ} \mathrm{C}$ (January) to $45^{\circ} \mathrm{C}$ (July) with an average humidity of $30 \%$. Barley and corn ground grains were obtained from one source that was used in all of the studies. Cereal grains were ground by a hammer mill (screen size $=3 \mathrm{~mm}$ ). The barley and corn grains were firstly screened for removing small kernels and chaff, then steamed (inlet temperature of $60^{\circ} \mathrm{F}$ and outlet temperature of $212^{\circ} \mathrm{F}$ and PSI=113.4) in a vertical steam chamber (stainless steel) for $30 \mathrm{~min}$ and then flaked by large rollers (46×90 Flaking Mill, FerrellRoss, Amarillo, factory of Aryadan, Khorasan-Razavi, Province) to obtain the desired flake density (360 g/L). The grains were dried processed by a clean and concrete commodity shed, transferred into the farm, and mixed with the other ingredients in a feed mixer.

\section{Animals and Experimental Procedures}

Forty postpartum multiparous lactation Holstein cows with a weight mean of $570 \pm 40 \mathrm{~kg}$ and milk yield mean of $30.00 \pm 2.1 \mathrm{~kg} /$ day were used in a completely randomized design. All the used procedures were in agreement with the Animal Care and Use Committee of Islamic Azad University, Arak Branch (IAUA4506). Cows were divided into 4 groups $(n=10)$ and fed diets containing 1) Ground grains (control); 2) Steam flacked corn+milled barley (SCMB); 3) Steam flacked barley+milled corn (SBMC); and 4) Steam flaked corn and barley (SCB) for a 120-day period after calving. Diets were prepared on the basis of NRC requirements (NRC, 2001) for dairy cattle. Animals had free access to water and fed a total mixed ration twice at a day (09:00 and 17:00 h). All the feed ingredients were analyzed for chemical composition (Table 1).

\section{Milk Production and Compositions}

To determine milk production and compositions, milk yield was automatically recorded in four periods of 0-30, 30-60, 60-90, and 90-120 days after calving in the voluntary milking system after each milking (04:00 am, 12:00 pm, and 20:00 pm) and milk compositions (fat and protein) were weekly analyzed in all experimental period at the laboratory by a MilkoScan FT 120 (FOSS
Electric A/S, Hillerød, Denmark). A direct aseptic collection from the udder was used for the collection of samples through a sterile cannula.

\section{Reproductive Performance}

To evaluate the effects of the treatments on reproductive performance, the pregnancy rate in the first 100 days, total conception rate, average days to the first service (DFS), and open days. Diameters and the number of mature follicles were assessed by ultrasonography apparatus. The pregnancy rate in the first 100 days was defined as the percentage of cows confirmed pregnant within 100 days of calving, DFS was defined as mean days to the first service, and open days were defined as days from calving to conception, and total conception rate $(\%)$ was reported as the number of cows considered as pregnant in a period divided by the total number of inseminated cows.

Cows were inseminated after showing signs of heat. Pregnancy status was determined 3 times after artificial insemination (AI). To investigate the pregnancy status, milk progesterone concentration was measured on day 21 after AI by kits produced by OvuCheck Milk test Company (Biovet Inc., Canada) and trans rectal palpation and trans rectal ultrasonography were con-

Table 1. Feed and chemical composition of experimental diets

\begin{tabular}{lcccc}
\hline \multirow{2}{*}{ Item (\%) } & \multicolumn{4}{c}{ Treatments } \\
\cline { 2 - 5 } & Control & SCMB & SBMC & SBC \\
\hline Alfalfa hay & 19.95 & 19.95 & 19.95 & 19.95 \\
Corn silage & 22.0 & 22.0 & 22.0 & 22.0 \\
Ground barley & 15.03 & 15.03 & 0 & 0 \\
Ground corn & 17.33 & 0 & 17.33 & 0 \\
Steam flacked barley & 0 & 0 & 15.03 & 15.03 \\
Steam flaked corn & 0 & 17.33 & 0 & 17.33 \\
Cotton seed & 7.02 & 7.02 & 7.02 & 7.02 \\
Soybean meal & 9.43 & 9.43 & 9.43 & 9.43 \\
Canola meal & 3.01 & 3.01 & 3.01 & 3.01 \\
Wheat bran & 2.9 & 2.9 & 2.9 & 2.9 \\
Sodium bicarbonate & 1.09 & 1.09 & 1.09 & 1.09 \\
Calcium carbonate & 0.55 & 0.55 & 0.55 & 0.55 \\
Salt, mineral, and & 1.69 & 1.69 & 1.69 & 1.69 \\
vitamins* & & & & \\
Chemical composition & & & & \\
$\quad$ DM, \% & 51 & 51 & 51 & 51 \\
NEL, Mcal/kg & 1.51 & 1.56 & 1.61 & 1.7 \\
CP, \% & 15.4 & 15.4 & 15.4 & 15.4 \\
TDN, \% & 72 & 74 & 74 & 74 \\
NDF, \% & 25 & 25 & 25 & 25 \\
Ca, \% & 0.69 & 0.69 & 0.69 & 0.69 \\
P, \% & 0.44 & 0.44 & 0.44 & 0.44 \\
\hline
\end{tabular}

Note: $\mathrm{SCMB}=$ Steam flacked corn with milled barley; SBMC= Steam flacked barley with milled corn; $\mathrm{SBC}=$ Steam flacked corn and barley; $\mathrm{DM}=$ dry matter; $\mathrm{NE}=$ net energy; $\mathrm{TDN}=$ total digestible nutrients; $\mathrm{NDF}=$ neutral detergent fiber.

* $=$ Contained $19.6 \% \mathrm{Ca}, 9.6 \% \mathrm{P}, 7.1 \% \mathrm{Na}, 1.9 \% \mathrm{Mg}, 0.3 \% \mathrm{Fe}, 0.03 \%$ $\mathrm{Cu}, 0.2 \% \mathrm{Mn}, 0.3 \% \mathrm{Zn}, 100$ ppm Co,100 ppm I, 0.1 ppm Se, $50 \times 105$ IU of vitamin A, $10 \times 105 \mathrm{IU}$ of vitamin D, and $0.1 \mathrm{~g}$ of vitamin E/ $\mathrm{kg}$. 
ducted on days 35 and 60-90. Total conception rate was estimated as the number of cows considered as pregnant in a period divided by the total number of inseminated cows in 35 days after the first AI.

\section{Reproduction and Metabolic Disorders}

Reproductive disorders (endometritis and pyometra) and metabolic disorders (ketosis and acidosis) were investigated in all the experimental period as $0=$ not affected and 1= affected. Endometritis was characterized as a discharge containing flecks of pus from the cow vagina in 21 days to 42 days after calving (Williams et al., 2005). Pyometra was characterized as a presence of purulent or mucopurulent fluid in the uterus with the presence of a corpus luteum and a closed cervix within 42 to $60 \mathrm{~d}$ after calving (Sheldon et al., 2008). Acidosis was reported as a decreased alkali (excessive acid) in the body fluids (Dehkordi \& Dehkordi, 2011). Clinical signs of ketosis were anorexia, depression, and odor of acetone in the breath (Güntner et al., 2018).

\section{Feed Intake}

Feed consumption was separately and daily measured for all the experimental animals after collecting and weighing orts before the noon milking. To investigate the dry matter (DM) contents, the precision amount of feed consumption was subtracted from the DM content of orts.

\section{Rumen $\mathrm{pH}$ and Fermentation}

At the end of the trial period, a sample of rumen fluid per cow $4 \mathrm{~h}$ was collected after the first daily feeding by a stomach tube. The collection was based on 4-h sampling for showing a precise $\mathrm{pH}$, as was reported by a previous study (Nordlund \& Garrett, 1994). The initial $200 \mathrm{~mL}$ of fluid aspirated was removed for minimizing saliva contamination. A portable digital $\mathrm{pH}$ meter (HI 8318, Hanna Instruments Cluj-Napoca, Romania) was used for the assessment of $\mathrm{pH}$. A cheese-cloth with a mesh size of $250 \mu \mathrm{m}$ was used to squeeze the samples. We preserved $10-\mathrm{mL}$ of the filtrate by adding $2 \mathrm{~mL}$ of $25 \%$ HPO3 for the determination of volatile fatty acid (VFA) and then stored at $20^{\circ} \mathrm{C}$ for subsequent analyses. Following thawing in room temperature (i.e. $20^{\circ} \mathrm{C}$ ), ruminal fluid was assessed by GC (Chrompack, Model CP-9002, Chrompack, EA Middelburg, the Netherlands) with a 50-m (0.32-mm i.d.) fused silica column (CP-Wax Chrompack Capillary Column, Varian, Palo Alto, CA). Crotonic acid and nitrogen were used as an internal standard and carrier gas, respectively. Initial and final oven temperatures were $55^{\circ} \mathrm{C}$ and $195^{\circ} \mathrm{C}$, respectively, while the detector and injector temperatures were controlled at $250^{\circ} \mathrm{C}$.

\section{Statistical Analysis}

Statistical procedures were conducted using SAS/ STAT 9.4 (SAS Institute Inc., Cary, NC, 2013). Since the disorders have a binary nature and are not neces- sarily distributed in a normal manner, a generalized linear mixed model linked by logistic regression (PROC GLIMMIXED) was used. The below model was used for the analysis of data:

$$
\operatorname{Logit} \pi)=\alpha+\text { treat }_{i}+\text { parity }_{j}+\beta\left(D P_{l}-\overline{D P}\right)+\text { Cow }_{m}
$$

A linear mixed model for the analysis of production and reproduction traits was used. The following model was used for the analysis:

$Y_{i j k m}=\mu+$ treat $_{i}+$ parity $_{j}+$ period $_{k}+\left(\right.$ treat $\times$ period $_{i k}+\beta\left(D P_{l}-\overline{D P}\right)+$ Cow $_{m}+e_{i j k l m}$

where $\Pi$ was an odds ratio of disorder (acidosis, ketosis, endometritis, and Pyometra), $\alpha$ is an intercept, $Y_{i j k l m}$ was dependent variable (milk production traits or reproductive performance), $\mu$ was the overall mean, treati was the fixed effect of the treatment ( $\mathrm{i}=1,2,3$ and 4$)$, parity was the fixed effect of the treatment parity $(j=1,2,3$ and 4 ), period ${ }_{k}$ was the fixed effect of 4 periods and is only used for production traits), treat $x$ period was an interaction effect of the treatment and period (only for production traits), $\beta$ was regression coefficient of observations in previous days (DP), Cow $w_{m}$ was cow effect, and $e_{i j k m}$ was a residual effect. The significant differences among the treatment were considered at a significant level of $\mathrm{p}<0.05$.

\section{RESULTS}

\section{Daily Dry Matter Intake (DMI)}

DMI was significantly lower in steam flaked grains or combined form group compared to the other groups. Results showed that SCB had $17.8 \mathrm{~kg} /$ day and it was lower than other treatments.

\section{Milk Yield and Compositions}

The effects of dietary inclusion of steam flaking of barley and corn grains on milk yield and milk compositions are shown in Table 2. The results showed that average daily milk and the levels of fat and protein were not significantly different in the treatments in the first period of the experiment $(0-30 \mathrm{~d})$. The results also showed that the inclusion of steam flaking of barley and corn grains into the diet significantly increased the average daily milk and milk fat percentage during the second (30-60 d) and third (60-90 d) periods of the study compared to control group $(p<0.05)$. However, dietary inclusion of steam flaked grains significantly increased milk yield, milk compositions, and $4 \%$ fat corrected milk during the fourth period of the experiment (90-120 d) compared to the control group $(\mathrm{p}<0.05)$.

\section{Reproduction and Metabolic Disorders}

Estimated odds ratios for the effects of dietary steam flaked of barley and corn on reproductive and metabolic disorders of postpartum cows are shown in Table 3. The results for logistic regression analysis showed that the cows in steam flaked treatments showed a lower occurrence for reproductive disorders (endometritis and pyometra) and metabolic disorders 
Table 2. Milk yields and compositions in postpartum cows fed steam flaked of barley and corn

\begin{tabular}{|c|c|c|c|c|c|}
\hline \multirow{2}{*}{ Variables } & \multicolumn{4}{|c|}{ Treatments } & \multirow{2}{*}{$\mathrm{p}$-value } \\
\hline & Control & SCMB & SBMC & SCB & \\
\hline \multicolumn{6}{|l|}{$\operatorname{Milk}(\mathrm{kg} / \mathrm{d})$} \\
\hline $0-30$ & $29.66 \pm 1.21$ & $29.80 \pm 1.13$ & $29.95 \pm 1.43$ & $31.00 \pm 1.09$ & 0.412 \\
\hline $30-60$ & $30.77 \pm 0.98^{c}$ & $34.19 \pm 1.41^{b}$ & $36.15 \pm 0.85^{a}$ & $34.45 \pm 1.01^{b}$ & 0.021 \\
\hline $60-90$ & $33.46 \pm 0.51^{b}$ & $35.00 \pm 0.82^{a}$ & $36.10 \pm 0.93^{a}$ & $38.55 \pm 2.21^{\mathrm{a}}$ & 0.012 \\
\hline $90-120$ & $34.45 \pm 0.58^{c}$ & $37.12 \pm 1.01^{b}$ & $36.81 \pm 0.91^{\mathrm{b}}$ & $39.20 \pm 0.81^{\mathrm{a}}$ & 0.011 \\
\hline \multicolumn{6}{|l|}{ Fat (\%) } \\
\hline $0-30$ & $3.32 \pm 0.11$ & $3.25 \pm 0.09$ & $3.25 \pm 0.09$ & $3.25 \pm 0.08$ & 0.751 \\
\hline $30-60$ & $3.23 \pm 0.07^{b}$ & $3.41 \pm 0.07^{a}$ & $3.39 \pm 0.06^{\mathrm{a}}$ & $3.42 \pm 0.08^{a}$ & 0.023 \\
\hline $60-90$ & $3.23 \pm 0.05^{b}$ & $3.40 \pm 0.07^{a}$ & $3.36 \pm 0.08^{a}$ & $3.42 \pm 0.09^{a}$ & 0.031 \\
\hline $90-120$ & $3.28 \pm 0.08^{b}$ & $3.41 \pm 0.05^{\mathrm{a}}$ & $3.44 \pm 0.04^{\mathrm{a}}$ & $3.55 \pm 0.10^{\mathrm{a}}$ & 0.026 \\
\hline \multicolumn{6}{|l|}{ Protein $(\%)$} \\
\hline $0-30$ & $3.14 \pm 0.06$ & $3.12 \pm 0.05$ & $3.11 \pm 0.09$ & $3.12 \pm 0.09$ & 0.358 \\
\hline $30-60$ & $3.20 \pm 0.04^{b}$ & $3.37 \pm 0.09^{a}$ & $3.36 \pm 0.08^{a}$ & $3.40 \pm 0.09^{a}$ & 0.031 \\
\hline $60-90$ & $3.15 \pm 0.08^{b}$ & $3.36 \pm 0.07^{a}$ & $3.38 \pm 0.06^{a}$ & $3.39 \pm 0.09^{a}$ & 0.028 \\
\hline $90-120$ & $3.16 \pm 0.08^{b}$ & $3.36 \pm 0.11^{\mathrm{a}}$ & $3.38 \pm 0.10^{\mathrm{a}}$ & $3.34 \pm 0.10^{\mathrm{a}}$ & 0.035 \\
\hline \multicolumn{6}{|l|}{$4 \%$ FCM } \\
\hline $0-30$ & $26.31 \pm 0.91$ & $26.76 \pm 0.88$ & $26.52 \pm 1.08$ & $27.50 \pm 1.97$ & 0.512 \\
\hline $30-60$ & $27.60 \pm 1.08^{b}$ & $31.23 \pm 0.88^{\mathrm{a}}$ & $32.90 \pm 1.04^{\mathrm{a}}$ & $32.32 \pm 2.02^{\mathrm{a}}$ & 0.009 \\
\hline $60-90$ & $32.41 \pm 0.88^{\mathrm{b}}$ & $34.82 \pm 1.01^{\mathrm{a}}$ & $36.61 \pm 1.38^{a}$ & $35.00 \pm 1.28^{\mathrm{a}}$ & 0.031 \\
\hline $90-120$ & $40.15 \pm 1.12^{c}$ & $43.92 \pm 1.07^{b}$ & $47.15 \pm 0.58^{\mathrm{a}}$ & $47.95 \pm 0.98^{\mathrm{a}}$ & 0.021 \\
\hline DMI (\%) & $18.40 \pm 0.21^{\mathrm{a}}$ & $18.50 \pm 0.18^{\mathrm{a}}$ & $18.50 \pm 0.21^{\mathrm{a}}$ & $17.80 \pm 0.11^{\mathrm{b}}$ & 0.021 \\
\hline
\end{tabular}

Note: $\mathrm{SCMB}=$ Steam flacked corn with milled barley; $\mathrm{SBMC}=$ Steam flacked barley with milled corn; SCB: Steam flacked corn and barley; FCM= fat corrected milk: $0.432 \times$ milk $(\mathrm{kg})+16.23 \times$ fat $(\mathrm{kg})$; DMI= dry matter intake. Means in the same row with different superscripts differ significantly $(\mathrm{p}<0.05)$.

Table 3. Estimated odds ratios (95\% confidence interval) for the effects of dietary steam flaked of barley and corn on incidence of reproduction and metabolic disorders in postpartum cows

\begin{tabular}{lccccc}
\hline \multirow{2}{*}{ Disorders } & \multicolumn{4}{c}{ Treatments } & \multirow{2}{*}{ p-value } \\
\cline { 2 - 5 } & Control & SCMB & SBMC & SBC & 0.001 \\
Endometritis & $1(0.8-1.0)$ & $0.66(0.46-0.86)$ & $0.39(0.16-0.52)$ & $0.19(0.12-0.35)$ & 0.001 \\
Pyometra & $1(0.8-1.0)$ & $0.54(0.38-0.75)$ & $0.51(0.36-0.67)$ & $0.27(0.13-0.48)$ & 0.001 \\
Ketosis & $1(0.8-1.0)$ & $0.6(0.39-0.89)$ & $0.57(0.33-0.78)$ & $0.001(0.0-99.0)$ & 0.001 \\
Acidosis & $1(0.8-1.0)$ & $0.42(0.19-0.68)$ & $0.27(0.11-0.43)$ & $0.001(0.0-99.0)$ & \\
\hline
\end{tabular}

Note: SCMB= Steam flacked corn with milled barley; SBMC= Steam flacked barley with milled corn; SCB= Steam flacked corn and barley.

(ketosis and acidosis) $(\mathrm{p}<0.001)$. The occurrence of endometritis was reduced in animals fed with steam flaked grains so that the greatest odds of endometritis were observed in the control group (odds ratios $=1, \mathrm{p}<0.01$ ). In contrast, the animals fed SBC showed the lowest odds of endometritis (odds ratios $=0.19$ ). The odds ratio of pyometra in the animals fed SCMB and SBMC was almost half of the control treatment, and it was decreased to 0.27 in the SBC group. The rate of ketosis in SCMB and SBMC groups was significantly lower compared to the control group $(p<0.05)$. The use of corn and barley steam flaked in dairy cattle during postpartum period decreased odds of acidosis abnormality $(p<0.05)$.

\section{Ruminal Fermentation Characteristics}

The results for ruminal fermentation characteristics are shown in Table 4 . The results showed that $\mathrm{pH}$ was significantly higher in cows fed steam flaked compared to the control group $(\mathrm{p}<0.05)$. The results showed that total VFA, acetate, propionate, butyrate, and valerate were significantly higher in cow fed steam flaked compared to the control group $(\mathrm{p}<0.05)$. Isovalerate and caproate were not influenced by the experimental treatments.

\section{Reproduction Responses}

The results in Table 5 showed that the number and diameter of mature follicles were not affected by dietary steam flaked of barley and corn treatments. The number of mature follicles in the cows treated with the steam flacked, especially SBC group, was numerically higher compared to the control group. The mature follicle diameter in the control and SBMC groups was the same $(17.5 \mathrm{~mm})$, but these parameters were significantly lower in the SCMB and SBC groups compared to the control group $(p=0.08)$. The results also showed that the 
inclusion of a combination of steam flaked of barley and corn significantly increased pregnancy rate in the first 100 days of postpartum cows compared to control and a single form of steam flaked barley or corn $(\mathrm{p}<0.05)$ (Table 6). The total conception rate was not influenced by the treatments. The average days to the first service tended to be a significant increase $(p=0.06)$ in the experimental treatments. The animals in experimental treatments containing steam flaked of barley and corn grains, either individually or in combination, showed favorable results on the average open days that were statistically significant $(p<0.05)$. The best results for the open days were observed in the treatment of steam flaked corn with milled barley (95.1 days). The results showed that the use of corn and barley steam flaked replaced with ground grains improved $11.5 \mathrm{~d}$ open days in postpartum cows (Table 6).

\section{DISCUSSION}

In the current study, the animals in control (ground grains) and steam flaked grains groups showed significant differences for open days, ruminal fermentation characteristics, metabolic disorders, milk yield, and milk compositions that is likely attributed to the differences in the grain processing and diet composition. Grain processing provides starch accessibility for microbes and enhances the rate of starch degradation in the rumen (Dehghan-banadaky et al., 2007). The use of steam flaked grains increases the digestibility of dry matter in the total digestive tract, the absorption of nutrients in the mammary glands, and in turn, increases the milk production in cows (Cooke et al., 2008). Heat processes during the steam flaking process increase the fermentation efficiency by changing the endosperm protein matrix and starch structure (gelatinization) that result in improving microbial digestibility (Cooke et al., 2008; Van Vuuren et al., 2010).

Milk production and energy efficiency of commercial lactating dairy cows have enhanced during recent decades, parallel with the decreased reproductive performance (Lucy, 2001; Dobson et al., 2008). Ansari-Lari et al. (2010) reported days open was increased 0.3 days per $100-\mathrm{kg}$ increase for milk production. Based on reproductive response and milk production, feeding steam flaked barley and corn grain, especially in combination form improved reproductive health, productivity, and milk production through modulation in the intestinal

Table 4. Ruminal fermentation characteristics of postpartum cows fed steam flaked of barley and corn

\begin{tabular}{lrrrrr}
\hline \multirow{2}{*}{ Variables } & \multicolumn{3}{c}{ Treatments } & \multirow{2}{*}{ p-value } \\
\cline { 2 - 4 } & \multicolumn{1}{c}{ Control } & \multicolumn{1}{c}{ SCMB } & \multicolumn{1}{c}{ SBMC } & \multicolumn{1}{c}{ SCB } & 0.042 \\
$\mathrm{pH}$ & $6.10 \pm 0.04^{\mathrm{c}}$ & $6.30 \pm 0.05^{\mathrm{b}}$ & $6.30 \pm 0.05^{\mathrm{b}}$ & $6.50 \pm 0.03^{\mathrm{a}}$ & 0.003 \\
Total VFA (mmol/L) & $81.20 \pm 2.31^{\mathrm{b}}$ & $97.10 \pm 3.18^{\mathrm{a}}$ & $96.31 \pm 3.73^{\mathrm{a}}$ & $100.20 \pm 4.17^{\mathrm{a}}$ & 0.002 \\
Acetate $(\mathrm{mol} / 100 \mathrm{~mol})$ & $51.20 \pm 2.14^{\mathrm{b}}$ & $57.60 \pm 3.13^{\mathrm{a}}$ & $57.31 \pm 3.19^{\mathrm{a}}$ & $60.10 \pm 3.48^{\mathrm{a}}$ & 0.032 \\
Propionate $(\mathrm{mol} / 100 \mathrm{~mol})$ & $17.10 \pm 1.15^{\mathrm{b}}$ & $21.10 \pm 0.98^{\mathrm{a}}$ & $22.31 \pm 1.08^{\mathrm{a}}$ & $22.10 \pm 0.99^{\mathrm{a}}$ & 0.004 \\
Butyrate $(\mathrm{mol} / 100 \mathrm{~mol})$ & $7.20 \pm 0.75^{\mathrm{b}}$ & $10.10 \pm 0.38^{\mathrm{a}}$ & $9.91 \pm 0.69^{\mathrm{a}}$ & $10.10 \pm 0.21^{\mathrm{a}}$ & 0.002 \\
Valerate $(\mathrm{mol} / 100 \mathrm{~mol})$ & $2.20 \pm 0.05^{\mathrm{a}}$ & $1.80 \pm 0.12^{\mathrm{b}}$ & $1.81 \pm 0.08^{\mathrm{b}}$ & $1.91 \pm 0.18^{\mathrm{b}}$ & 0.721 \\
Isovalerate $(\mathrm{mol} / 100 \mathrm{~mol})$ & $1.20 \pm 0.28$ & $1.10 \pm 0.21$ & $1.31 \pm 0.25$ & $1.10 \pm 0.27$ & 0.292 \\
Caproate $(\mathrm{mol} / 100 \mathrm{~mol})$ & $0.72 \pm 0.07$ & $0.81 \pm 0.16$ & $0.75 \pm 0.09$ & $0.85 \pm 0.14$ & 0.29 \\
\hline
\end{tabular}

Note: $\mathrm{SCMB}=$ Steam flacked corn with milled barley; SBMC= Steam flacked barley with milled corn; SCB= Steam flacked corn and barley. Means in the same row with different superscripts differ significantly $(\mathrm{p}<0.05)$.

Table 5. Diameter and number of mature follicles of postpartum cows fed steam flaked of barley and corn

\begin{tabular}{|c|c|c|c|c|c|}
\hline \multirow{2}{*}{ Variables } & \multicolumn{4}{|c|}{ Treatments } & \multirow{2}{*}{$\mathrm{p}$-value } \\
\hline & Control & SCMB & SBMC & SBC & \\
\hline Number of mature follicles & $1.30 \pm 0.26$ & $1.30 \pm 0.26$ & $1.50 \pm 0.24$ & $1.60 \pm 0.26$ & 0.09 \\
\hline Mature follicle diameter (mm) & $17.58 \pm 0.47$ & $16.74 \pm 0.47$ & $17.54 \pm 0.47$ & $16.98 \pm 0.43$ & 0.08 \\
\hline
\end{tabular}

Note: $\mathrm{SCMB}=$ Steam flacked corn with milled barley; SBMC= Steam flacked barley with milled corn; SCB= Steam flacked corn and barley.

Table 6. Reproduction responses in postpartum cows fed steam flaked of barley and corn

\begin{tabular}{lccccc}
\hline \multirow{2}{*}{ Variables } & \multicolumn{2}{c}{ Treatments } & \multirow{2}{*}{ p-value } \\
\cline { 2 - 5 } & Control & SCMB & SBMC & SBC & \multirow{2}{*}{0.01} \\
\cline { 1 - 4 } $\begin{array}{l}\text { Pregnancy rate in the first 100 } \\
\text { days (\%) }\end{array}$ & $26.0 \pm 3.0^{\mathrm{b}}$ & $23.0 \pm 4.0^{\mathrm{b}}$ & $27.0 \pm 2.5^{\mathrm{b}}$ & $39.0 \pm 3.0^{\mathrm{a}}$ & \\
Total conception rate (\%) & $48.00 \pm 3.59$ & $50.00 \pm 3.15$ & $51.00 \pm 4.08$ & $51.00 \pm 2.21$ & 0.10 \\
DFS (d) & $61.1 \pm 2.0$ & $61.5 \pm 3.0$ & $60.8 \pm 1.0$ & $57.9 \pm 4.0$ & 0.06 \\
Open days (d) & $106.6 \pm 3.0^{\mathrm{a}}$ & $95.1 \pm 2.0^{\mathrm{b}}$ & $97.5 \pm 2.0^{\mathrm{b}}$ & $96.2 \pm 2.0^{\mathrm{b}}$ & 0.04 \\
\hline
\end{tabular}

Note: $\mathrm{SCMB}=$ Steam flacked corn with milled barley; SBMC= Steam flacked barley with milled corn; SCB $=$ Steam flacked corn and barley. ${ }^{*}=\mathrm{Average}$ days to the first service. Means in the same row with different superscripts differ significantly $(p<0.05)$. 
and ruminal microbial ecosystem and fermentation efficiency. Previous studies have shown milk response to steam flaked grain was higher than responses obtained with the other energy sources during postpartum period (Dehghan et al., 2007; Safaei et al., 2016, 2017). Milk yield and compositions (fat and protein) efficiency was higher in the cows treated with continuous feeding of steam flaking of barley and corn grains supplementation for $120 \mathrm{~d}$. Using steam in the processing of grains improves the digestive efficiency due to the release of nutrients, increases feed and energy efficiency that is used for milk synthesis (Koening et al., 2013; Safaei et al., 2017). Milk production and compositions are the main economic factors for dairy cow farmers. Our findings are in agreement with those reported by others (Dehghan et al., 2007; Safaei et al., 2016). Previous studies have shown that unprocessed grains reduced the fiber and protein digestion, and volatile fatty acids production, particularly propionic acid and increased microbial mass (Koing \& Beauchemin, 2011). These happen likely decreased milk yield and milk fat content of cows fed milled grain compared to flacked grains.

Conversely, other studies have not observed the significant effect of steam flaking of corn and barley on milk production of dairy cows (Ghorbani et al., 2016; Safaei et al. 2017). The differences between our findings and the others could be explained by breed, amount, and type of basal diet as well as different types of grain in the diet. The quality of processed cereal grain could be influenced by a combination of factors such as heat, moisture, time, and mechanical action (Kokić et al., 2013). The results showed that ruminal $\mathrm{pH}$ was significantly lower in cows treated with steam flaked grains, but total VFA and fatty acids were higher in the treated cows.

Santos et al. (1997) showed that grains processed by steam improve digestive conditions and increases energy and protein intake that eventually reduced the need for food. Studies have reported that the use of steam in the processing of grains improves the digestive efficiency due to releasing nutrients, improving digestion in the rumen and increasing feed efficiency (Koening et al., 2013; Safaei et al., 2017). Conversely, previous studies have shown that processing methods (grinding vs. steam flaking) did not have a significant effect on DMI (Ghorbani et al., 2016; Safaei et al., 2017). The mentioned studies show only limited effects of the steam flaking method on DMI in cows. A better understanding of the rate of feed intake can help to prepare better nutritional management programs for dairy cows.

The energetic state is a factor influencing fertility in dairy cows. Bodyweight was rapidly decreased in a negative energy balance in postpartum cows (Sirotkin et al., 2013). Opsomer (2009) showed that high-producing cows were more susceptible to metabolic disorders due to their negative energy balances and due to the limited capacity of feed intake in the early postpartum and increased milk production in cows. A negative energy balance will be associated with the occurrence of disruptions of health and physiological condition (Garnsworthy et al., 2008; Tajik et al., 2009). On the other hand, Ferguson et al. (2006) reported that a sharp drop in the body condition score increases the likelihood of infertility by 7 times. There is a direct correlation between high productions with the occurrence of abnormalities in cows. One of the parameters influencing the outbreak of rumen acidosis is the high levels of non-fiber carbohydrates in the ration (Razavi et al., 2019). Our findings in Table 3 show that feeding flaked of barley and corn has beneficial effects on reproductive disorders (endometritis and pyometra) and metabolic disorders (acidosis and ketosis). The results showed that grain steam processing provides the required energy and protein for overcoming reproductive and metabolic disorders of dairy cows during postpartum. The results for rumen fermentation confirmed the decreased acidosis in cows treated with steam flaked grains. Rumen acidosis is defined by the decrease of rumen $\mathrm{pH}$. The results showed a higher occurrence of acidosis in steam flaked groups. It means lower acidosis in the treated groups. It is well known that acidosis increases the fermentation of carbohydrates (Bramley et al., 2008). The results show that ruminal fatty acids were lower in cows fed steam flaked grains that show the degradation of carbohydrates in the rumen and possible degradation in the intestine system. Acidosis is usually in $\mathrm{pH}<5.5$, but our findings are higher. It can be implicated that acidosis is not only associated with $\mathrm{pH}$ and other factors influence it. In the current study, we considered several factors for acidosis as reported by Dehkordi \& Dehkordi (2011), including rumen overload, hypovolemia, associated with loss or compartmentalization of containing fluid, pregnancy toxemia, loss of bicarbonate-rich saliva with oral disease or esophagostomy in cattle, gastrointestinal loss of bicarbonate as a result of diarrhea, and renal failure that may decrease the ability to excrete hydrogen and thus retain bicarbonate.

Physiological changes following parturition in dairy cows will influence the next lactation. Providing nutrients plays a key role in productive and reproductive performances in this period. The results showed that the inclusion of corn and barley steam flaked into diet improved the pregnancy rate, open days, and average days to the first service (Table 5). Cow's ability is faulted for inducing estrus and improving the health of the uterus for the subsequent pregnancy due to the decreased feed intake in early lactation and increased milk production at the same time. Duru \& Can Baycan (2019) showed that calving interval and days to the first service were increased in high milk-yielding cows compared to low milk yielding cows. Providing nutrients, especially digestible energy, could thus improve the nutrients and requirements. On the basis of previous studies, flakes of seeds used in the ration of dairy cattle have positive effects on ovarian function and pregnancy rate (Garnsworthy et al., 2008; Koening et al., 2013; Yang et al., 2013). Based on the results of this study, feeding flaked barley and corn improved production and reproductive performance in the early lactation period in dairy cows. To avoid the costs of reproductive loss and early replacement costs in dairy cows feed, surplus costs required for processing the flakes are needed. In sum, high reproduction responses in commercial high-producing multiparous dairy cattle may be partly explained 
by cow breeds that have sufficient energy and protein for supporting pregnancy and alleviating disorders that may change the ruminal fermentation pattern.

\section{CONCLUSION}

Feeding about $15 \%-17 \%$ steam flaked of barley and corn has significant interaction effects on milk production, ruminal fermentation, milk compositions, and pregnancy rate in the SBC group during postpartum period. It is suggested to assess the effects of steam flaked method on the expression of genes involved in metabolism and reproduction.

\section{CONFLICT OF INTEREST}

The authors declare that there is no conflict of interest with any financial, personal, or other relationships with other people or organization related to the material discussed in the manuscript.

\section{ACKNOWLEDGEMENT}

The authors appreciate farm management for financial assistance and his cooperative for conducting this study.

\section{REFERENCES}

Ansari-Lari, M., M. Kafi, M. Sokhtanlo, \& H. N. Ahmadi. 2010. Reproductive performance of Holstein dairy cows in Iran. Trop. Anim. Health. Prod. 42: 1277-1283. https://doi. org/10.1007/s11250-010-9561-y

Atmakusuma, J., B.M. Sinaga, N. Kusnadi, \& I. K. Kariyasa. 2019. The impact of external and internal factors on the dairy farmer's household economics. Trop. Anim. Sci. J. 42: 245-252. https://doi.org/10.5398/tasj.2019.42.3.245

Bramley, E., I. J. Lean, W. J. Fulkerson, M. A. Stevenson, A. R. Rabiee, \& N. D. Costa. 2008. The definition of acidosis in dairy herds predominantly fed on pasture and concentrates. J. Dairy. Sci. 91: 308-321. https://doi.org/10.3168/ jds.2006-601

Cooke, K. M., J. K. Bernard, \& J. W. West. 2008. Performance of dairy cows fed annual ryegrass silage and corn silage with steam-flaked or ground corn. J. Dairy. Sci. 91: 2417-2422. https://doi.org/10.3168/jds.2007-0715

Corato, A., S. Segato, \& I. Andrighetto. 2005. Effects of extruded corn on milk yield and composition and blood parameters in lactating dairy cows. Ital. J. Anim. Sci. 4: 166-168. https://doi.org/10.4081/ijas.2005.3s.166

Dehghan-banadaky, M., R. Corbett, \& M. Oba. 2007. Effects of barley grain processing on productivity of cattle. Anim. Feed. Sci. Technol. 137: 1-24. https://doi.org/10.1016/j. anifeedsci.2006.11.021

Dehkordi, A. J., \& Z. K. Dehkordi. 2011. Occurrence of metabolic alkalosis in rumen lactic acidosis: a review. Compar. Clin. Pathol. 20: 1-3. https://doi.org/10.1007/s00580-010-1129-8

Dobson, H., S. L. Walker, M. J. Morris, J. E. Routly, \& R. F. Smith. 2008. Why is it getting more difficult to successfully artificially inseminate dairy cows?. Anim. 2: 1104-1111. https://doi.org/10.1017/S175173110800236X

Duru, S. \& S. Can Baycan. 2019. Change of daily milk yield during estrous period in Holstein cattle raised under Mediterranean climate. Trop. Anim. Health. Produc. 51: 1571-1577. https://doi.org/10.1007/s11250-019-01857-7

Ferguson, J. D., G. Azzaro, \& G. Licitra. 2006. Body condition assessment using digital images. J. Dairy. Sci. 89: 38333841. https://doi.org/10.3168/jds.S0022-0302(06)72425-0

Ghorbani, G. R., F. Ahmadi, \& M. Haidary. 2016. Effect of steam-flaked and ground corn with different particle size on dairy cow performance with high-concentrate diet. J. Anim. Sci. 94: 701. https://doi.org/10.2527/jam2016-1446

Garnsworthy, P. C., J. G. Gong, D. G. Armstrong, J. R. Newbold, M. Marsden, S. E. Richards, G. E. Mann, K. D. Sinclair, \& R. Webb. 2008. Nutrition, metabolism, and fertility in dairy cows: 3 . Amino acids and ovarian function. J. Dairy. Sci. 91: 4190-4197. https://doi.org/10.3168/ jds.2008-1035

Güntner, A. T., J. F. Kompalla, H. Landis, S. J. Theodore, B. Geidl, N. A. Sievi, M. Kohler, S. E. Pratsinis, \& P. A. Gerber. 2018. Guiding ketogenic diet with breath acetone sensors. Sensors. 18: 3655. https://doi.org/10.3390/ s18113655

Koening, K. K. Beauchemin, \& W.Z. Yang. 2013. Processing feed grain: factors affecting the effectiveness of grain processing for beef and dairy cattle production. Processing of 34th western nutrition conference-processing, performance and profit, Saskatoon, Saskatchewan, Canada. p. 62-73.

Koing, K., \& K. Beauchemin. 2011. Optimum extent of barley grain processing and barley silage proportion in feedlot cattle diets: Growth, feed efficiency and fecal characteristics. Canad. J. Anim. Sci. 91: 411-422. https://doi. org/10.4141/cjas2010-039

Kokić, B., J. Lević, M. Chrenková, Z. Formelová, M. Poláčiková, M. Rajský, \& R. Jovanović. 2013. Influence of thermal treatments on starch gelatinization and in vitro organic matter digestibility of corn. Food. Feed. Res. 40 (Suppl. 2): 93-99.

Lucy, M. C. 2001. Reproductive loss in high-producing dairy cattle: where will it end?. J. Dairy. Sci. 84: 1277-1293. https://doi.org/10.3168/jds.S0022-0302(01)70158-0

Moharrery, A., G. Himoller, \& M.R. Weisbjerg. 2017. The effect of rolled barley, sodium hydroxide-treated wheat or maize cob silage on digestive enzymes activity in the alimentary tract of dairy cows. J. Anim. Feed. Sci. 26: 303-310. https:// doi.org/10.22358/jafs/80039/2017

Nikkhah. A., M. Alikhani, \& H. Amanlou. 2004. Effects of feeding ground or steam-flaked broom sorghum and ground barley on performance of dairy cows in midlactation. J. Dairy. Sci. 87: 122-130. https://doi.org/10.3168/jds. S0022-0302(04)73149-5

Nordlund, K. \& E. Garrett. 1994. Rumenocentesis: a technique for collecting rumen fluid for the diagnosis of subacute rumen acidosis in dairy herds. Bovine. Practitioner. 28: 109-112.

NRC. 2001. Nutrient Requirements of Dairy Cattle. 7th rev. edn. Natl Acad Press, Washington, DC.

Opsomer, G. \& A. Kriuf. 2009. Metritis and endometritis in high yielding dairy cows. Vlaams. Diergeneeskundig. Tijdschrift. 78: 83-88.

Razavi, S. A., M. Pourjafar, A. Hajimohammadi, R. Valizadeh, A. A. Naserian, R. Laven, \& K. R. Mueller. 2019. Effects of dietary supplementation of bentonite and Saccharomyces cerevisiae cell wall on acute-phase protein and liver function in high-producing dairy cows during transition period. Trop. Anim. Health. Prod. 51: 1225-1237. https://doi. org/10.1007/s11250-019-01815-3

Razzaghi, A., M. Larsen, P. Lund, \& M. R. Weisbjerg. 2016. Effect of conventional and extrusion pelleting on in situ ruminal degradability of starch, protein and fiber in cattle. Livest. Sci. 185: 97-105. https://doi.org/10.1016/j. livsci.2016.01.017

Safaei, K. H., G. R. Ghorbani, M. Alikhani, A. Sadeghi Sefidmazgi, W.Z. Yang, \& F. Mohammadi. 2016. Effects of 
processing method, steaming duration and roller setting distance on ruminal degradability of barley grain. J. Rum. Res. 3: 103-126.

Safaei, K. H., G. R. Ghorbani, M. Alikhani, A. Sadeghi Sefidmazgi, \& W. Z. Yang. 2017. Response of lactating dairy cows to degree of steam-flaked barley grain in lowforage diets. J. Anim. Physiol. Anim. Nutr. 101: 87-97. https://doi.org/10.1111/jpn.12565

Safaei, K.H. \& W.Z. Yang. 2017. Effects of Grain Processing with Focus on Grinding and Steam-Flaking on Dairy Cow Performance. In: Herbivores. pp. 118-131. https://doi. org/10.5772/67344

Santos, F. A. P., J. T. Huber, G. B. Theurer, R. S. Swingle, Z. Wu, J. M. Simas, K. H. Chen, S. C. Chan, J. Santos, \& E. J. DePeters. 1997. Comparison of barley and sorghum grain processed at different densities for lactating cows. J. Dairy. Sci. 80: 2098-2103. https://doi.org/10.3168/jds. S0022-0302(97)76155-1

Sheldon, I. M., E. J. Williams, A. N. Miller, D. M. Nash, \& S. Herath. 2008. Uterine diseases in cattle after parturition. Vet. J. 176: 115-121. https://doi.org/10.1016/j.tvjl.2007.12.031

Sirotkin, A.V., A.V. Makarevich, P. Makovicky, \& E. Kubovicova. 2013. Ovarian, metabolic and endocrine indexes in dairy cows with different body condition scores. J. Anim. Feed. Sci. 22: 316-322. https://doi.org/10.22358/ jafs $/ 65919 / 2013$

Tajik, J., M. G. Nadalian, A. Raoofi, G. R. Mohammadi, \& A. R. Bahonar. 2009. Prevalence of subacute ruminal acidosis in some dairy herds of Khorasan Razavi province northeast of Iran. Iran. J. Vet. Res. 1: 28-32.
Theurer, C., H. Huber, \& F. Santos. 1995. Feeding and managing for maximal milk protein, Southwest Nutrition and Management Conference.

Van Vuuren, A. M., V. A. Hindle, A. Klop, \& J. W. Cone. 2010. Effect of maize starch concentration in the diet on starch and cell wall digestion in the dairy cow. J. Anim. Physiol. Anim. Nutr. 94: 319-329. https://doi. org/10.1111/j.1439-0396.2008.00911.x

Williams, E. J., D. P. Fischer, D. U. Pfeiffer, G. C. England, D. E. Noakes, H. Dobson, \& I. M. Sheldon. 2005. Clinical evaluation of postpartum vaginal mucus reflects uterine bacterial infection and the immune response in cattle. Theriogenology 63: 102-117. https://doi.org/10.1016/j. theriogenology.2004.03.017

Xu, N., J. Liu, \& P. Yu. 2018. Alteration of biomacromolecule in corn by steam flaking in relation to biodegradation kinetics in ruminant, revealed with vibrational molecular spectroscopy. Spectrochimica. Acta Part A. Mol. Bimolecul. Spectroscopy. 19: 491-497. https://doi.org/10.1016/j. saa.2017.10.040

Yang, W.Z., M. Oba, \& T. A. Mc Allister. 2013. Quality and precision processing of barley grain affected intake and digestibility of dry matter in feedlot steers. Canad. J. Anim. Sci. 93: 251-260. https://doi.org/10.4141/cjas2012-132

Zinn, R., F. Owens, \& R. Ware. 2002. Flaking corn: processing mechanics, quality standards, and impacts on energy availability and performance of feedlot cattle. J. Anim. Sci. 80 (Suppl. 5): 1145-1156. https://doi. org/10.2527/2002.8051145x 